\title{
ATTAINING VALUE FROM PRIVATE INVESTMENT IN POWER GENERATION PROJECTS IN INDONESIA: AN EMPIRICAL STUDY
}

\author{
Gigih Atmo*, Colin Duffield, David Wilson \\ Department of Infrastructure Engineering, School of Engineering, The University of Melbourne, Australia
}

(Received: December 2014 / Revised: January 2015 / Accepted: February 2015)

\begin{abstract}
Provision of electrical infrastructure in emerging economies, like Indonesia, is very challenging post the 2008 Global Financial Crisis (GFC). Constrained lending via international finance markets has led to a reduction in the number of investors and shorter lending periods for public private partnerships (PPPs) projects. While domestic Indonesian investors and banks have begun to be involved in such projects, the scale of budgetary requirements for the delivery of power plant projects generally exceeds the financial capacity of both the public sector and local financial markets.
\end{abstract}

This paper presents the findings of a Delphi style survey and proposes implementation strategies that may overcome current investment constraints and still attain Value for Money (VfM) from the delivery of Indonesian PPP power projects post the 2008 GFC. Initially, qualitative data was acquired from two industry seminars to establish the context of Indonesian PPP power projects. This was followed by two rounds of the Delphi technique to develop consensus among a panel of industry experts about realizing VfM from Indonesian PPPs. The results show that (i) export credit agencies from regional Asian countries have increased their roles to support PPP power projects (ii) structural deficiencies of local power industry manufacturing has created barriers for greater roles of local finances in the projects (iii) enhanced contractual risk allocation between the public and private sector can potentially improve project outcomes; these involve greater transparency and accountability of project guarantee processes. This study adapted key implementation features for attaining VfM into short, medium, and long term development strategies that are suitable for Indonesia. It has been concluded that a sustainable energy system can be realized when there is alignment of interests between the government, project sponsors, fuel suppliers, and lenders.

Keywords: PPP Project finance structure, value for money, power plant, public private partnerships.

\section{INTRODUCTION}

Indonesia as one of the emerging economies in Asia has experienced a significant growth in its Gross Domestic Products of 5.8\% annually over the last decade (The World Economic Forum, 2014). It is however identified that economic infrastructure such as electrical generation requires a significant amount of investment to sustain the economic growth of the country.

\footnotetext{
*Corresponding author. E-mail: gigih.atmo@gmail.com
} 
The electricity sector requires US\$ 97.06 billion of new electrical generation infrastructure from 2015 and 2024 where more than half of the investment is expected to come from private power generation companies (Perusahaan Listrik Negara, 2014). The Indonesian government has introduced various policies relating to public private partnerships (PPPs) as a mechanism to attract private investment to power plant projects. Nonetheless, international project finance markets have been challenging post the 2008 Global Financial Crisis (GFC) and this has delayed the anticipate investment.

Public-private partnerships (PPP) as an alternative procurement strategy from traditional approaches have been widely implemented in many countries, both developed as well as developing. Although there is no single agreed definition about PPPs (Grimsey and Lewis, 2005), in this research PPPs are defined as a long term contractual risk sharing between a public authority and the private sector whereby the private sector is responsible for design, financing, construction, and operation of public infrastructure while the government pays for the agreed level of services delivered by the private sector. This definition fits into the context of PPPs in power plant projects whereby payments for the private sector are from the government on the basis of availability-based payment and electric energy generations. The availability-based payment is manifested into a capacity charge in power projects that is adequate to serve the private sector debt payments and to provide expected returns on investment (Woodhouse 2006; Wells and Ahmad 2007). Accordingly, this PPP definition includes two groups of Indonesian PPP program, namely: the Independent Power Producers (IPPs) and the Indonesian Public Private Partnerships. The former has been introduced since the 1990s while the later has been introduced in 2005 through the Presidential Regulation number 67/2005 about Partnerships between Government and private sector business entities.

Private investors have become more risk averse to infrastructure projects post the GFC in 2008 (Regan et al., 2011). In mature PPP markets such the UK and Australia, the private sector is willing to accept systematic risks such as regulatory risk and macroeconomic risk (Cheung et al., 2010). On the contrary, the private sector perceives high political risks in an emerging country's PPPs like China (Chan et al., 2010) and Indonesia (Conrad et al., 2008). Support from government for private investment in public private partnerships (PPPs) is expected to restore confidence among infrastructure investors in project finance markets for power infrastructure projects. The support post GFC mainly concentrates on financial assistance either directly or in-directly to project consortia such as debt guarantee, debt contribution or even equity participation (Acerete et al., 2010). In today's project finance market, potential private investors often requested government support which can change the structure of project risk allocation between the public and private sector in a PPP project (Fitzgerald and Duffield, 2009).

It is acknowledged that budget pressures for infrastructure delivery occur in developed and developing nations. Governments can raise debt on a fully-recourse basis through government bonds to finance traditionally procured infrastructure projects (Siemiatycki, 2013). Countries that have advanced experience in PPPs like the United Kingdom and Australia only deliver PPPs when they offer better VfM than the alternative traditional public procurement (Cheung et al., 2009; Infrastructure Australia, 2008a; HM Treasury - United Kingdom 2012; Greve and Hodge, 2013).VfM can be defined as an economic outcome of efficiency and effectiveness that results from complex balancing between cost, risk, and performance of a PPP project (Grimsey and Lewis, 2005; Clifton and Duffield, 2006). They use Public Sector Comparator as a project governance process to calculate whether PPP project proposals offer higher benefits or lower costs than the alternative traditional public procurement (Infrastructure Australia 2008b). The Productivity Commission of Australia provided indicative estimates of PPPs shares of total government infrastructure programs. PPPs represent only 5\% and 16\% of total infrastructure program in 
Australia and the United Kingdom respectively (Chan et al. 2009). Interestingly, the share of PPPs in emerging economies like Indonesia is much higher. For instance, PPPs account for around $65 \%$ of the Indonesian power generation future development program between 2015 and 2024 (Perusahaan Listrik Negara, 2014).

Figure 1 illustrates the Indonesian power development program between PPPs and traditional procurement for a period between 2015 and 2024. It shows that private investment in PPP power projects are expected to outnumber the public sector investment in terms of capital expenditure for project development costs and installed power capacity. The primary motivation for developing countries engaging with the private sector through PPP mechanisms is to gain access to private capital for delivering public infrastructure (Deloitte Touche Tohmatsu Emerging Markets, 2004; Jiang and Wamuziri, 2008). It is important to put more weight on VfM consideration for PPPs in emerging economies because they are accounted for large share of infrastructure development program.

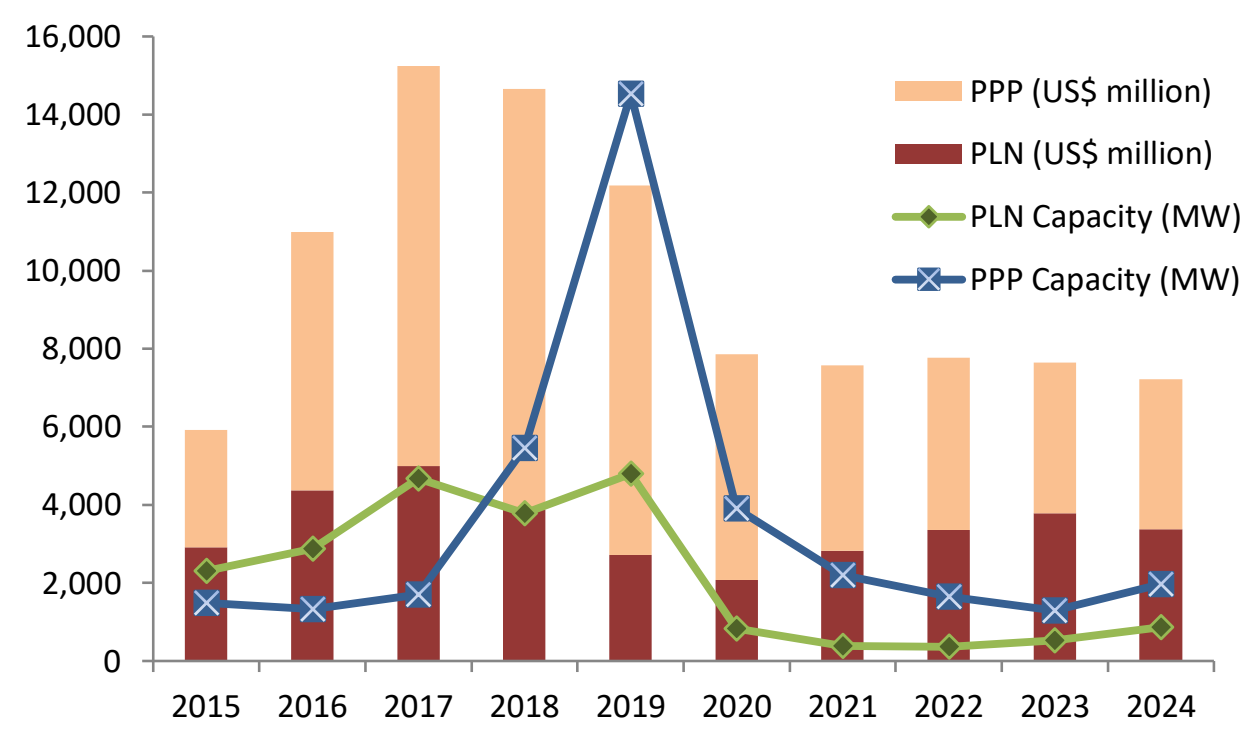

Figure 1. Power plant development program (2015 - 2024)

(source of data: Perusahaan Listrik Negara (2014))

Atmo and Duffield (2014) proposed key implementation strategies to attain VfM from PPPs in power generation projects on the basis of evaluation of the six power plant projects in Asia that were procured between 1994 and 2007. The strategies focus on the realization of five VfM drivers that are essential to attain VfMs in PPPs power projects, namely: enabling environment, appropriate risk allocation, enhanced tender competition processes, consideration for innovation and whole-of-life costing, and strategic utilization of private sector skills. The proposed strategies contain alignment between domestic resource capabilities and international project finance markets to create a PPP project structure that can deliver sustainable energy outcomes through balancing performance between energy security, environmental sustainability, and price affordability. Domestic resources capabilities include participation from local financial institution, energy companies, and equipment manufacturers in project finance structure of a PPP power project.

This paper seeks to test the validity of the key implementation strategies proposed by Atmo and Duffield (2014) in the current context of power project procurement post the 2008 global financial crisis and to test finance industries appetite for investing in such projects in Indonesian PPP power programs. It proposes enhanced key implementation strategies to 
attain VfM from Indonesian PPPs that considers for the first time the progressive maturity of Indonesian PPP markets. The strategies are detailed into short, medium, and long term PPP development processes and take into consideration: the complexity of governing processes of Indonesian PPPs, the maturity of the power plant manufacturing industry and project finance markets in Indonesia, and the emerging structure of international project finance markets post the 2008 global financial crisis.

This paper is structured such that it introduces the context of infrastructure power projects in emerging economies post the 2008 GFC. It goes on to outline the three stages of iterative research processes which were based on the Delphi technique to adapt the implementation strategies for attaining VfM in the context of Indonesian PPP power projects. The paper synthesizes findings from this study to construct appropriate implementation strategies that are divided into short, medium, and long term development strategies.

\section{METHODOLOGY}

A Delphi style questionnaire approach has been adopted as it is considered the most efficient study method for investigating expert opinions from various professional backgrounds (Gallego and Bueno, 2014). A number of studies have combined qualitative and quantitative research approaches between rounds of a Delphi study to improve the clarity of what a market is saying, for instance Anil et al. (2014) investigated Grand Challenges for the Indian construction industry. The number of rounds suggested for a Delphi method is between two and three rounds (Landeta, 2006). It is acknowledged that a Delphi study has a potential subjectivity that arises from varied levels of experience, knowledge, and perceptions of the research participants (Franklin and Hart, 2007). This issue has been addressed in this research through careful selection of participants in the Delphi study and triangulation of the results of the study using the analysis from the transcripts and presentation materials of the two industrial seminars on PPPs. The participants were all closely associated with the power industry and had deep understanding of the technologies, regulations and culture of the Indonesian and international power industry. They would qualify as experts in the international power industry.

This study included two-rounds of a Delphi process as outlined in Figure 2. The first stage, establishing the context, involved a detailed literature review followed by attendance at two industry seminars where approval was obtained to record the proceedings for later analysis. The industry seminars provided a rich source of information on the updated context of VfM drivers in Indonesian power projects post the 2008 global financial crisis. The second stage involved an initial Delphi survey incorporating the results of the industrial seminars for further investigation. The participants of the Delphi survey (two iterations) were organized by the Indonesian Ministry of Finance and involved both the public and private participants in Indonesian PPP projects. The third stage of the study involved a focus group discussion where the results of the surveys and seminars were presented.

Of the 62 participants at the workshops a total of 53 valid responses were returned for the analysis, indicating a response rate of $85 \%$. The area of expertise of participants is illustrated through the pie chart in Figure 3. Using a Likert scale of one to five, the respondents were asked to evaluate the attractiveness of different forms of government support policies for PPPs in power projects, project risk profile and consequences, and attractiveness of an enhanced risk allocation scheme. 


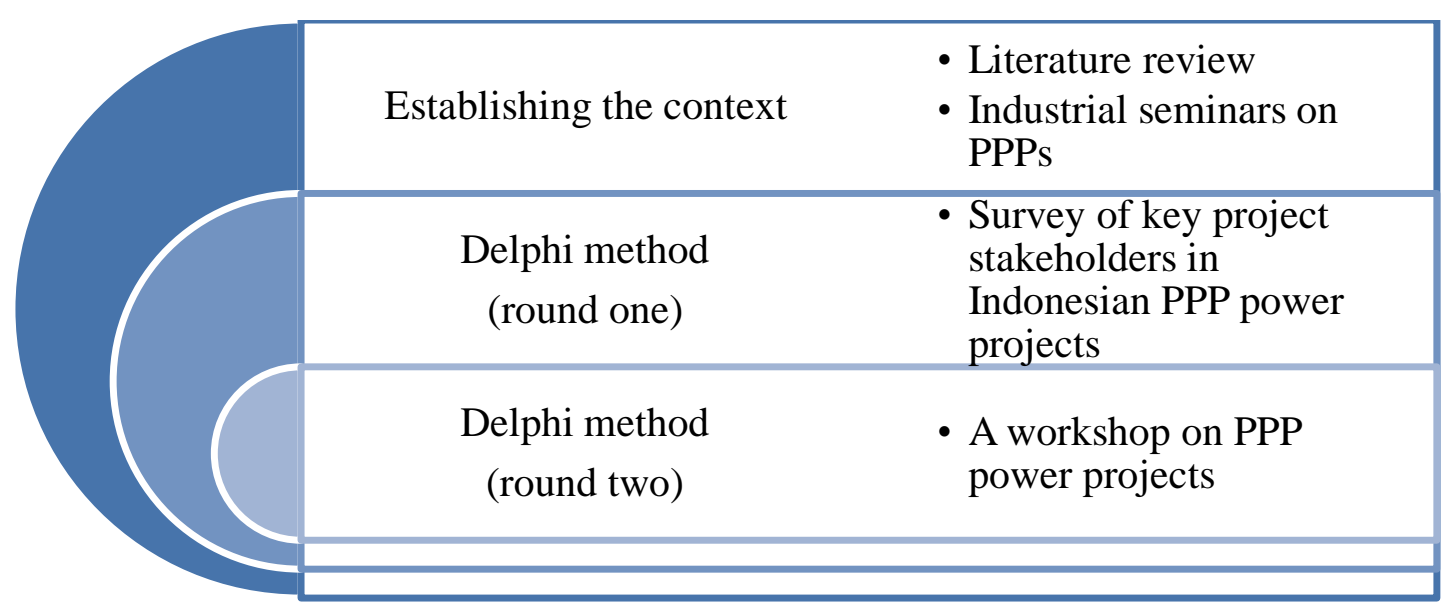

Figure 2. Methodology of Study

The five-point Likert scale contains 1 = most important, 2 = important, $3=$ medium, 4 $=$ less important, and $5=$ least important. This type of scale has been used to measure responses from project stakeholders in PPP projects. For example, Li et al. (2005) used the Likert scale for investigating critical success factors of PPP projects in the United Kingdom while Ke et al. (2013) evaluated risk allocation of PPP projects in China using a five-point Likert survey.

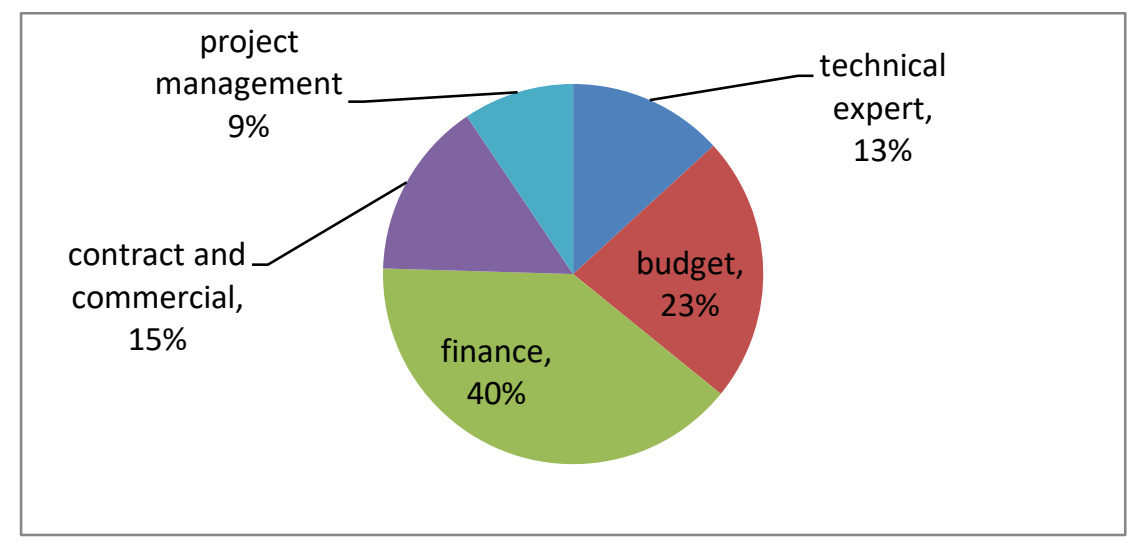

Figure 3. Demographic area of expertise of the survey participants

The questionnaire data were analysed using the Mean Score Ranking technique, refer equation (1).

$$
M S=\frac{\sum(f \times l)}{N}
$$

Where:

\section{MS : Mean score}

$l \quad:$ the score given between a five point Likert scale (1-5) where one represents the most important while five is the least important.

$f \quad$ : the frequency of score

$\mathrm{N} \quad$ : Total number of survey participants

The major findings from the two round Delphi study and participating in the two international industrial seminars on PPP power projects are summarized in the next section of this paper. 


\section{RESULTS AND DISCUSSION}

The findings are presented under the broad headings of motivation for using PPPs, attractiveness of government support, perceived risk profile of Indonesian PPP power projects, and attractiveness of enhanced risk allocation scheme.

\subsection{Attractiveness of Government Support for Indonesian PPP Power Projects}

The qualitative data have revealed that international project finance markets have experienced substantial changes post the 2008 global financial crisis. This study reveals that project debt contributions from regional Export Credit Agencies (ECAs) have become more important following the constrained liquidities of commercial finance institutions in the delivery of PPP power projects. Project finance markets have tended to cluster into regions whereby emerging ECAs from countries like China, South Korea, and India have become more active to seek investment opportunities in regional markets. Traditional project investors from Japan have continued to show their strong presence in the development of Indonesian PPP power projects. However, gaining participation from foreign ECAs often requires government guarantees. While domestic banks have increased their participation in such projects, their limited liquidities in foreign currencies have constrained their abilities to provide long term debt finance.

This study has found that government support is favourable to address risks in Indonesian PPP power projects post the 2008 GFC. The findings from the industrial seminar data have demonstrated that potential private investors, particularly foreign ECAs, are most concerned with the state electric company, Perusahaan Listrik Negara (PLN), financial capabilities to serve its obligation under the Power Purchase Agreement. The Indonesian government initiative to establish the Indonesia Infrastructure Guarantee Fund (IIGF) with support from the World Bank has received favourable responses from potential project sponsors and financiers. This guarantee institution improves transparency and accountability processes in the provision of government guarantees and becomes the institution the private sector must approach for government guarantees. It has the capabilities to undertake risk due diligence to ensure a PPP project proposal is commercially feasible.

While government guarantees are considered important to address project systematic risks, the survey results highlighted the importance for government assistance to address project specific risks. It can be seen from Table 1 that there are four government support features favourable for PPP project stakeholders, namely: centralised business permit applications, government grants for managing high project risk, fuel supply arrangements, and project equity contributions.

It appears that the private sector considers provision of a one stop service for business permit applications as equally important as the availability of a government guarantee in Indonesian PPP power projects. There were concerns from project sponsor representatives in the seminars and workshop that they needed to establish two separate contracts for the development of geothermal power projects. The project sponsors required to contract with the local government for geothermal resource development and with the PLN for the Power Purchase Agreement. These processes have introduced complexity in the project contractual structuring. 
Table 1. Attractiveness of different forms of government support in PPP power projects

\begin{tabular}{lcc}
\hline \multicolumn{1}{c}{ Attractiveness of government policies to mitigate limited market } \\
\multicolumn{1}{c}{$\begin{array}{l}\text { liquidities } \\
\text { score }\end{array}$} & Rank \\
\hline $\begin{array}{l}\text { Provision of clarity and speed for obtaining permits and other } \\
\text { statutory requirements (one-stop over for business permits } \\
\text { application) }\end{array}$ & 1.55 & $=1$ \\
b) Government guarantee & 1.55 & 1 \\
c) Government grant to improve project financial feasibility (e.g. & 2.11 & 7 \\
$\begin{array}{l}\text { provision of viability gap fund) } \\
\text { d) Project equity contribution }\end{array}$ & 2.02 & 5 \\
e) Project debt contribution & 2.07 & 6 \\
f) Government financial assistance for managing high project & 1.83 & 3 \\
g) Taxk (e.g. revolving fund in geothermal power project) & 2.24 & 8 \\
h) Fuel supply security is assured by the government & 1.98 & 4 \\
\hline
\end{tabular}

Project sponsors of a PPP power project require permits and approvals from various governmental organisations before they can commence project construction activities. These include adherence of the project with the Regional Long-term Development Plan from the local government, regulations of environmental impact assessment from the Ministry of Environment, and the General Plan of Electricity from the Ministry of Energy and Mineral Resources. While all of these regulations are considered important, these regulatory processes may create barriers for the private sector to fast track the development of power plant facilities.

Besides the provision of one-stop business application service, government financial contribution in a PPP power project and assurance on fuel supply by the government were ranked in the top five most favourable types of government support. The private project sponsors expect government financial assistance to manage resource development risk in geothermal power projects. This type of project specific risk is considered high to project financiers. The government has mandated the Indonesia Investment Agency (IIA) to manage the Geothermal Fund Facility through the Ministry of Finance regulation number 03/2012. The IIA can finance preliminary surveys to enhance the quality of geothermal resources that reduces the geothermal exploration risks to the private sector. The institution can also provide assistance on structuring contractual documents for geothermal power projects such that they meet international lender requirements. In addition to the government support through the Geothermal Fund Facility, the IIA can contribute into the financial structure of a PPP power project through provision of long term low interest loan package or project equity contribution. Nevertheless, the IIA's investment was focused mainly in medium to small scale renewable energy projects (e.g. Mini hydro power plants with installed capacities of less than 10 Mega Watt).

Although domestic finance in local currency from mainly state banks is available, project construction cost requires a large proportion of finance in foreign currencies. The majority of power plant equipment has been imported from overseas because the local power industry has not been able to supply such equipment, especially for large scale power plants. As a result, purchasing of power plant products requires finance in foreign currencies, 
especially in the US dollar. International finance sources, particularly, ECAs are needed to fulfil a large proportion of project loans in foreign currencies. It is however noted that many international finance institutions have now supported energy projects that meet international standards of environmental sustainability. Accordingly, PPP power projects that utilise cleaner coal pulverised or renewable energy technologies have attracted broader ranges of project finance sources while conventional coal-fired power plants only attract limited pool of international investors.

\subsection{Perceived Risk Profile of Indonesian PPP Power Projects}

Commercial viability of a PPP power project is also influenced by project risk profile. Participants of the survey considered the project risk profile from Indonesian PPP power projects as illustrated in the risk matrix in Figure 4.

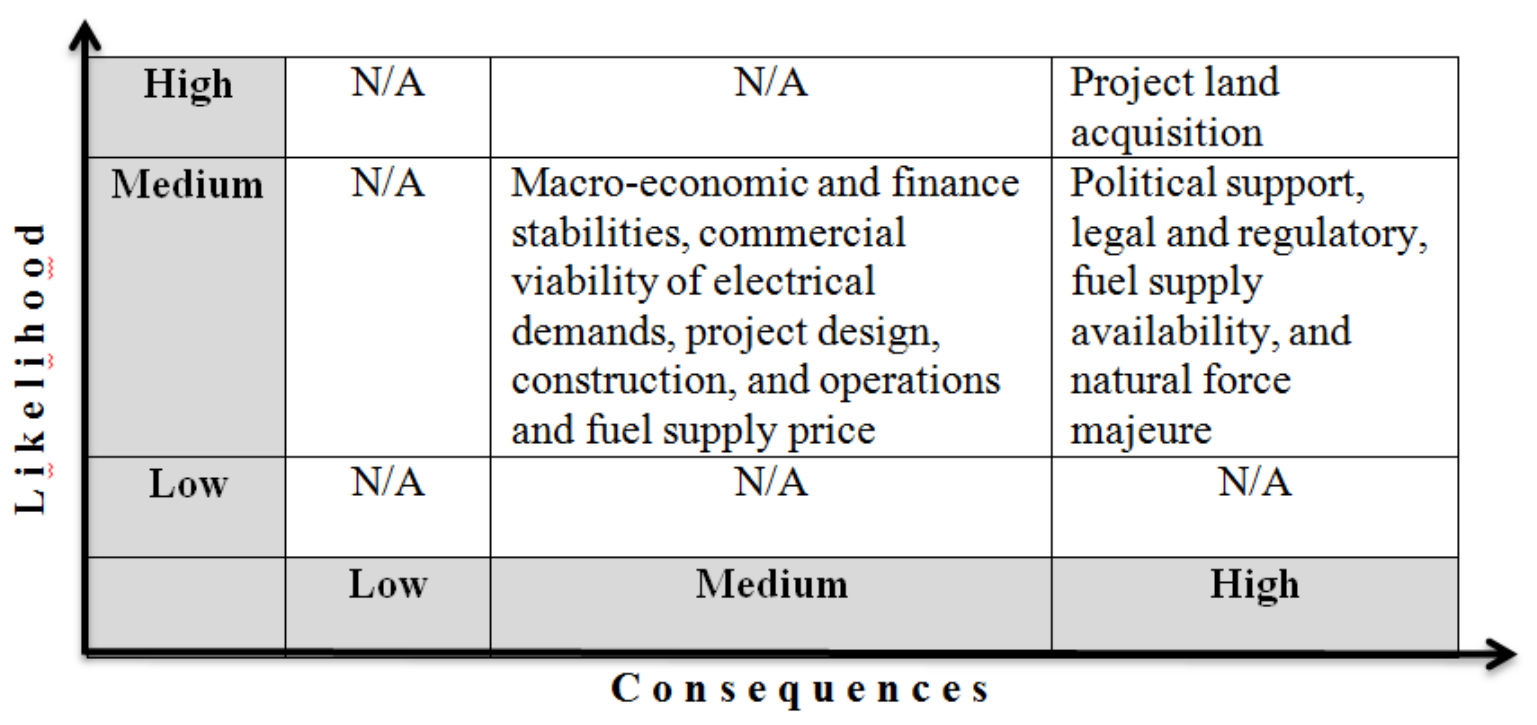

Figure 4. Risk matrix of PPP power projects based on the survey respondents

It appears that land acquisition has become an emerging barrier for the successful delivery of recent PPP power projects in Indonesia. One representative of project sponsors revealed the land price increase can cause about $20 \%$ cost overrun of the construction cost for a new medium size power project between 300 to $400 \mathrm{MW}$. In contrast, it only caused project cost escalation between 4 to $5 \%$ in the previous decade projects. Another issue that has been identified from a recent large scale PPP power project is that project construction can be delayed because some of the land owners do not agree to sell their land ownerships for the development of a power plant facility. It appears that allocating project land acquisition tasks to the private sector has resulted in suboptimal outcomes. If the government retains land acquisition activities in the delivery of PPP power projects it may produce enhanced project outcomes.

The project risk matrix in Figure 4 also shows five other risk sources that are considered to have high risk consequences. The IIGF, government guarantee institution, has been assigned to manage government guarantees for political risk including those associated with legal and regulatory risks. Fuel supply availability and natural force majeure require other risk management strategies. Foreign project lenders need assurance that a PPP power plant has secure access for long term energy supplies. According to the seminar data, there has been increasing number of coal energy companies that participate in PPP project consortia. This business strategy has been used by the coal companies to diversify against commodity price fluctuation in the international energy markets and to abide with the 
government regulation on Domestic Market Obligation. This energy policy obligates energy companies in Indonesia to sell a proportion of their energy supplies to Indonesian energy markets. It appears that energy company participation in Indonesian PPPs may have positive outcomes and become innovative strategies to manage fuel supply availability risk in PPP power projects.

Interestingly, there were a limited number of survey respondents who considered low risks in Indonesian PPPs power plant projects. Although the results are rather surprising, they are consistent with the seminar data on the progress of the second phase of the $10,000 \mathrm{MW}$ power development program. It was revealed that 16 out of 51 projects encountered problems associated with commercial and finance issues whilst the PPP success rate in a period between 2005 and 2009 was less than 45\% (Perusahaan Listrik Negara, 2012a; Perusahaan Listrik Negara, 2012b). Some potential investors were concerned with commercial viability of electricity consumer tariffs while complexities of procurement processes have increased contractual risks in geothermal power projects. Price fluctuation of primary energy commodities also introduces fuel supply risk to PPPs during the project operation phase. It appears that these risk factors have contributed to the perceived risk levels of Indonesian PPP power projects that fall into categories between medium to high risks.

\subsection{Attractiveness of Risk Allocation Scheme}

The survey also asked to consider the attractiveness of enhanced project risk allocation that was derived from the key implementation strategies in Atmo and Duffield (2014). Table 2 is used to validate risk mitigation strategies of four project risks that were considered high in previous studies such as Wells and Ahmad (2007) and Woodhouse (2006). The attractiveness of enhanced risk allocation is presented in Table 2. It can be seen that risk mitigation strategies for political risk (mean score 1.57) is considered the most important followed by fuel supply (mean score 2).

Table 2. the attractiveness of proposed new risk allocation

\begin{tabular}{|c|c|c|c|c|}
\hline Project risk & $\begin{array}{c}\text { Risk } \\
\text { Allocation }\end{array}$ & Mitigation strategies & Mean Score & Rank \\
\hline $\begin{array}{l}\text { Political } \\
\text { risk }\end{array}$ & Public & $\begin{array}{l}\text { - Guarantee is only to cover debt } \\
\text { obligation } \\
\text { - Private sector is charged with } \\
\text { premium commensurate with the } \\
\text { level of risk guaranteed } \\
\text { - The guarantee is provided through } \\
\text { Indonesia Infrastructure Guarantee } \\
\text { Fund } \\
\text { - Counter-guarantee from } \\
\text { international guarantor is not } \\
\text { provided }\end{array}$ & 1.57 & 1 \\
\hline $\begin{array}{l}\text { Currency } \\
\text { exchange } \\
\text { risk }\end{array}$ & Shared & $\begin{array}{l}\text { - The power purchase agreement } \\
\text { includes portion of Indonesian and } \\
\text { foreign currencies. The portion of } \\
\text { local tariff represents the percentage } \\
\text { of equity/debt structure from local } \\
\text { capital markets } \\
\text { - Provision of debt refinancing after } \\
\text { the project enters operating phase }\end{array}$ & 2.24 & 3 \\
\hline
\end{tabular}


Table Continued.

\begin{tabular}{|c|c|c|c|c|}
\hline Project risk & $\begin{array}{c}\text { Risk } \\
\text { Allocation } \\
\end{array}$ & Mitigation strategies & Mean Score & Rank \\
\hline $\begin{array}{l}\text { Accuracy } \\
\text { demand } \\
\text { forecasting }\end{array}$ & Shared & $\begin{array}{l}\text { - Capacity charge is reduced to only } \\
\text { provide a stable cash flow to serve } \\
\text { debt } \\
\text { - Profits are mainly from energy } \\
\text { charge } \\
\text { - Project consortium is allowed to } \\
\text { contract with a large scale } \\
\text { consumers for the excess capacity } \\
\text { above agreed capacity charge }\end{array}$ & 2.24 & $=3$ \\
\hline $\begin{array}{l}\text { Fuel supply } \\
\text { (price) }\end{array}$ & $\begin{array}{l}\text { Private } \\
\text { (Only for } \\
\text { private owning } \\
\text { fuel supply } \\
\text { business) }\end{array}$ & $\begin{array}{l}\text { - The fuel price is structured in local } \\
\text { currency } \\
\text { - Incentive for the private to produce } \\
\text { more electric power through } \\
\text { contract with large scale consumers }\end{array}$ & 2 & 2 \\
\hline
\end{tabular}

\subsection{Key implementation Strategies to Improve VfM in Indonesian PPP Power Projects}

A tailor-made VfM key implementation strategies that is suitable for procurement of Indonesian PPP power projects was developed. The tailored VfM strategies was constructed on the basis of findings by adapting the VfM strategies in Atmo and Duffield (2014) to the current context of Indonesian PPP markets post the 2008 global financial crisis. Key implementation strategies to attain VfM from Indonesian PPP power projects can be divided into three implementation time frames (Figure 5). The detailed discussion of each proposed VfM strategies follows:

\subsubsection{Short Term Strategies}

Immediate strategies that can be implemented to improve project outcomes of Indonesian PPP power projects consist of four key implementation strategies as outlined in Figure 5. Simplify business processes through creating a one stop government service. This can be applied to accommodate a newly established PPP Unit which has the authorities for preparing tendering processes and coordinating between government institutions (Wibisono et al., 2011). This institution has been prepared within the Ministry of Finance of Indonesia. The application of permits and other statutory requirements can be coordinated with the existing institutions such as the Indonesia Investment Coordinating Board to reduce complexity of bureaucratic processes undertaken by the project consortium. Accordingly consolidating of PPP processes into a single appointed institution can reduce the complexities of bureaucratic processes in Indonesia and it can be interpreted by the private sector as a favourable mechanism provided by the government to support the development of PPP program.

It has been found that foreign export credit agencies (ECAs) especially those from Asian regional economies have important roles in Indonesian PPP power projects. They often contribute to a large share of project debt structure and provide security to the international commercial lenders. Accordingly early engagement and consultation with ECAs by government project agencies during project initiation are important to align interests between the government and potential ECAs. International financiers including ECAs have praised the establishment of the Indonesia Infrastructure Guarantee Fund (IIGF) which encourages better transparency and accountability in the provision of government guarantees. They also often have a concern over security of energy supplies. These issues can be addressed through the 
state guarantee on long term fuel supplies security or the involvement of energy companies in a project consortium structure. Some project financiers especially from Japan and South Korea support projects that utilise cleaner power technologies including coal clean technologies and renewable-based power plant projects. It is therefore important to engage with potential project financiers during the project initiation process such that the structure and specification of power plant technologies can accommodate requirements from various potential lenders. Accordingly it can improve the level of tender competition and assure availability of financial support for PPP power projects.

\begin{tabular}{|c|c|c|}
\hline Short term & Medium term & Long term \\
\hline $\begin{array}{l}\text { Strengthening tendering } \\
\text { and guarantee processes } \\
\text { through the IIGF } \\
\text { institution. } \\
\text { Concentrate bureaucratic } \\
\text { processes of PPP power } \\
\text { projects in a single } \\
\text { appointed government } \\
\text { institution to reduce the } \\
\text { complexity of the } \\
\text { regulatory process. } \\
\text { Revise the standardize } \\
\text { contractual risk allocation } \\
\text { in PPA (e.g. land } \\
\text { acquisition, goethermal } \\
\text { resource development, } \\
\text { and fuel supply security). } \\
\text { Initiate early engagement } \\
\text { of foreign ECAs at the } \\
\text { country level during } \\
\text { project initiation process } \\
\text { to identify their interests } \\
\text { and commitments in a } \\
\text { PPP power project. }\end{array}$ & $\begin{array}{l}\text { Develop local finance } \\
\text { capabilities to support } \\
\text { PPP through provision of } \\
\text { long term debt finance in } \\
\text { local currency. } \\
\text { Increase local currency } \\
\text { payment portion in the } \\
\text { PPA tariff structure which } \\
\text { reflect the domestic power } \\
\text { industry capabilites. } \\
\text { Facilitate foreign } \\
\text { investment for power } \\
\text { plant manufacturing } \\
\text { industry (e.g. tax } \\
\text { incentives, state joint } \\
\text { venture). } \\
\text { Encourage utilisation of } \\
\text { local project developers } \\
\text { and power manufacturing } \\
\text { industry in the } \\
\text { development of } \\
\text { small/medium scale } \\
\text { power projects. }\end{array}$ & $\begin{array}{l}\text { Alignment economic } \\
\text { development policies } \\
\text { between domestic energy } \\
\text { resources utilisation, PPP } \\
\text { power program, and } \\
\text { industry clusters to } \\
\text { improve commercial } \\
\text { viability of PPP power } \\
\text { program. } \\
\text { Developing electricity } \\
\text { infrastructure as an asset } \\
\text { class which can provide } \\
\text { reliable long term cash } \\
\text { flows and hence } \\
\text { attractive to domestic } \\
\text { capital market investors. } \\
\text { Developing domestic } \\
\text { power industry } \\
\text { capabilities for highly } \\
\text { efficient thermal } \\
\text { combustions and } \\
\text { renewable power plant } \\
\text { technologies to support } \\
\text { the national electric } \\
\text { development program. }\end{array}$ \\
\hline
\end{tabular}

Figure 5. Government policy strategies for attaining VfM of Indonesian PPP power projects

\subsubsection{Medium Term Strategies}

For medium term strategies, the Indonesian PPP power projects need to benefit from diverse ranges of project sponsors, manufacturers, and financiers in the domestic and international markets. Key strategies in this time frame are to develop domestic power manufacturing industry and project finance markets to support procurement of power plant projects through a PPP mechanism. Utilisation of power plant equipment and contractors from the domestic market can reduce the development cost and require transactions in the local currency. Accordingly, domestic finance markets can have greater roles to finance and reduce currency exchange risks from PPP power projects.

The government can provide incentives to attract international power manufacturers to establish manufacturing facilities in Indonesia. These can include provision of financial packages like a tax holiday program and facilitate the establishment of either state or private joint venture companies with local manufacturers. The previous Chinese power projects of 
the Laibin-B and Shandong Zhonghua coal-fired power projects provide examples of construction cost reduction. These projects utilised local power turbines that were manufactured under international license from Alstom and Westinghouse respectively (Qiao et al., 2002; Woo, 2005). Utilisation of domestic power equipment that is manufactured according to international standards can potentially improve commercial viability of a PPP power project from the perspective of international financiers.

The development of the local power industry can also attract finance participants from the local banking and other financial institutions. This study found that availability of domestic loans in foreign currencies, particularly in the US dollar, has constrained local banks involvement in the lending transactions in a PPP power project. Project developers require finance in foreign currencies to import the main power plant equipment (e.g. generators, turbines, cooling towers, boilers). Availability of some power plant equipment from the local industry that require transactions in the local currency can potentially stimulate participation of local finance institutions where their sources of finance are predominantly in Indonesian currency.

\subsubsection{Long Term Strategies}

The sustainability of an Indonesian PPP power program can be improved through applying long term development strategies. It is important to create a commercially viable demand structure which provides adequate revenues for a PPP power plant. This project is independent from the need for government tariff subsidies that require political approval processes. This objective can be achieved through alignment between economic development policies of industrial economic zones or industrial complexes with PPP power development program. It can create commercially viable demand structures from industrial and business consumers for PPP power projects. Efficient fuel cost transportation can also improve commercial viability of a power plant project. National energy policies such as Demand Market Obligation (DMO) for the coal mining and natural gas industry can encourage utilisation of local energy resources to create efficient fuel supply costs during the project operation phase.

Sustainability of PPP power projects can also be improved through reducing project exposure to currency exchange risk by accessing available local project finance to develop PPP power projects. It is therefore important to encourage project consortia of PPP power projects to refinance their project debt structure in local currencies when power plant projects have entered into the commercial operation phase. In this project operating period, the project risk profile has been significantly reduced and therefore suitable for capital market investors such as pension funds and insurance companies who seek stable revenues.

The industrial seminars data has revealed the importance of environmental sustainability considerations into project lending due diligence processes. While renewablebased power projects have attracted broader finance sources, advanced clean coal technologies such as supercritical/ultra-supercritical pulverised boiler technologies receive support from foreign export credit agencies and multilateral development banks. Accordingly, national policies on the development of the local power industry may need to consider production of power plant equipment that complies with international environmental standards.

The above outlined implementation strategies to attain VfM from Indonesian PPP power projects have been detailed into three stages of project development time frames which consider the maturity of Indonesian PPP markets. 


\section{CONCLUSION}

This paper sought to test the validity of the appropriate implementation strategies to attain Value for Money (VfM) in the context of power procurement projects in Asian emerging economies and tested the finance industries appetite for investing in such projects in Indonesian PPP power programs. It has been found that implementation of key strategies to attain VfM from a PPP power project requires adaptation of the current structure of project finance markets post the 2008 global financial crisis. This paper highlights key results about current project finance structure: (i) there have been increasing finance transactions from regional Asian export credit agencies (ECAs) to support Indonesian PPP power projects, (ii) potential greater roles of local banks have been constrained by the necessity to import large proportions of power plant equipment that requires finance in foreign currencies, (iii) development of local manufacturing capabilities for power plant equipment is essential to strengthen project finance markets in Indonesia and reduces currency exchange risk from a PPP power project. The enhanced guarantee process through the IIGF institution has been innovative to manage political risk guarantees. Land acquisition has been considered as a high risk in recent Indonesian PPP power projects such that the government may consider assuming land acquisition risk. Enhanced contractual risk sharing for accuracy of demand forecasting and fuel supply security is possible through the alignment of industrial zone development policies and the inclusion of energy suppliers into project consortia. This paper discussed adapting key implementation strategies to attain VfM that considered progressive maturity of Indonesian PPP markets for power plant projects. These strategies were divided into short, medium, and long term project development strategies. Power plant procurement through a PPP mechanism has the potential to attain VfM but it involves complex transaction processes including complex financial arrangements and appropriate risk allocation to create a sustainable energy system.

This research investigates strategies to attain value for money from PPPs in power plant projects in Indonesia. It was based on responses from key project participants in the Delphi study and analysis of data from international seminars of PPP's in power projects that were held in Indonesia. The outcomes of this study can be applicable to other Asian emerging economies that have adopted the Single Buyer electricity market model as a transition to a more competitive electricity market. Asian regional economies like Vietnam, Thailand, Pakistan, and other countries might benefit from this research although adjustment to the country specific jurisdiction system and different level of PPP maturity are needed.

\section{ACKNOWLEDGMENT}

The first author wish to thank to the Ministry of Energy and Mineral Resources of Indonesia for providing a $\mathrm{PhD}$ scholarship and organizing a research workshop. He also would like to thank to the Ministry of Finance of Indonesia for assistance on conducting survey.

\section{REFERENCES}

Acerete, J.B., Shaoul, J., Stafford, A., Stapleton, P., (2010), The Cost of Using Private Finance for Roads in Spain and the UK, Australian Journal of Public Administration, Volume 69, pp. S48-S60.

Anil, S., Raghav, A., Virendra Kumar, P., (2014), Grand challenges for the Indian construction industry, Built Environment Project and Asset Management, Volume 4, pp. 317-334.

Atmo, G., Duffield, C., (2014), Improving investment sustainability for PPP power projects in emerging economies, Built Environment Project and Asset Management, Volume 4, pp. 335-351. 
Chan, A.P.C., Lam, P.T.I., Chan, D.W.M., Cheung, E., Yongjian, K., (2010), Critical Success Factors for PPPs in Infrastructure Developments: Chinese Perspective, Journal of Construction Engineering \& Management, Volume 136, pp. 484-494.

Chan, C., Forwood, D., Roper, H., Sayers, C., 2009. Public infrastructure financing: an international perspective, Productivity Commission Staff Working Paper. Productivity Commission of Australia, Melbourne, p. 269

Cheung, E., Chan, A.P.C., Stephen, K., (2009), Reasons for implementing public private partnership projects, Journal of Property Investment \& Finance, Volume 27, pp. 81-95.

Cheung, E., Chan, A.P.C., Kajewski, S., (2010), The public sector's perspective on procuring public works - comparing the views of practitioners in Hong Kong and Australia, Journal of Civil Engineering and Management, Volume 16, pp. 19-32.

Clifton, C. and Duffield, C.F., (2006), Improved PFI/PPP service outcomes through the a integration of Alliance principles, International Journal of Project Management, Volume 24 pp. 573-586.

Conrad, V., Andre, P., Tillmann, S., Robert, T., (2008), Political risk perception in Indonesian power projects, Journal of Financial Management of Property and Construction, Volume 13, pp. 18-34.

Deloitte Touche Tohmatsu Emerging Markets, (2004), Sustainable power sector reform in emerging markets - financial issues and options, Joint World Bank/USAID Policy Paper (June 2004).

Fitzgerald, J.P., Duffield, C.F., (2009), Value for Money in a changing world economy, in: Ng, S.T., Wong, J.M.W., Kumaraswamy, M. (Eds.), Symposium proceedings CIB TG72 titled 'Revisiting and Rethinking' to 'Revamping and Revitalising'. The University of Hong Kong, The University of Hong Kong, pp. 3 - 14.

Franklin, K. and Hart, J., (2007), Idea Generation and Exploration: Benefits and Limitations of the Policy Delphi Research Method, Innovative Higher Education, Volume 31, pp. 237-246.

Gallego, D., Bueno, S., (2014), Exploring the application of the Delphi method as a forecasting tool in Information Systems and Technologies research, Technology Analysis \& Strategic Management, Volume 26, pp. 987-999.

Greve, C., Hodge, G., (2013), Rethinking public-private partnerships : Strategies for turbulent times, Routledge critical studies in public management, London, UK ; New York, USA.

Grimsey, D., Lewis, M.K., (2005), Are Public Private Partnerships value for money?: Evaluating alternative approaches and comparing academic and practitioner views, Accounting Forum, Volume 29, pp. 345-378.

HM Treasury, (2012), A new approach to public private partnerships, HM Treasury of the United Kingdom, London, p. 100.

Infrastructure Australia, (2008a), National public private partnerships guidelines, Attorney General's Department of Australia, Canberra,p. 42.

Infrastructure Australia, (2008b), National public private partnerships guidelines: Volume 4 Public Sector Comparator guidance, Attorney General's Department of Australia, Canberra, p. 165.

Jiang, M., Wamuziri, S., (2008), Role of export credit agencies in PFI/PPP projects. Proceedings of the Institution of Civil Engineers: Management, Procurement and Law, Volume 161, pp. 163-169.

Ke, Y., Wang, S., Chan, A.P.C., (2013), Risk Misallocation in Public-Private Partnership Projects in China. International Public Management Journal, Volume 16, pp. 438-460.

Landeta, J., (2006), Current validity of the Delphi method in social sciences, Technological Forecasting and Social Change, Volume 73, pp. 467-482. 
Li, B., Akintoye, A., Edwards, P.J., Hardcastle, C., (2005), The allocation of risk in PPP/PFI construction projects in the UK. International Journal of Project Management, Volume 23 , pp. 25-35.

Perusahaan Listrik Negara, (2012a), Pengembangan PLTP IPP. Perusahaan Listrik Negara, EBTKE Conex, Jakarta, p.20.

Perusahaan Listrik Negara, (2012b), Public Private Partnership: PPA Model and Risk Allocation: Lesson Learnt from Central Java CSFPP 2 x 1000 MW. Perusahaan Listrik Negara, Masyarakat Ketenagalistrikan Indonesia Workshop, Jakarta, p.28.

Perusahaan Listrik Negara, (2014). Rencana usaha penyediaan tenaga listrik (RUPTL) PT PLN (Persero) 2015 - 2024, in: Perusahaan Listrik Negara (Ed.). Perusahaan Listrik Negara, Jakarta, p. 491.

Qiao, L., Wang, S.Q., Tiong, R.L.K., Chan, T.-S., (2002), Critical Success Factors for Tendering BOT Infrastructure Projects in China, Journal of Structured \& Project Finance, Volume 8, pp. 40-52.

Regan, M., Smith, J., Love, P.E.D., (2011), Impact of the Capital Market Collapse on PublicPrivate Partnership Infrastructure Projects, Journal of Construction Engineering \&Management, Volume 137, pp. 6-16.

Siemiatycki, M. in: Priemus, H., Wee, B.v. (Eds.), (2013), Public-private partnerships in mega-projects: successes and tensions, Edward Elgar Publishing, Inc. Cheltenham, pp. 133-157.

The World Economic Forum, (2014), The global competitiveness report 2014-2015: Full edition, in: Schwab, K. (Ed.), The Global Competitiveness Report ed. The World Economic Forum, Geneva, p. 549.

Wells, L.T., Ahmad, R., (2007), Making foreign investment safe: property rights and national sovereignty, Oxford : Oxford University Press.

Wibisono, A., Delmon, J., Hahm, H., (2011), Unlocking the public-private partnerships deadlock in Indonesia, The World Bank Jakarta Office. Jakarta, p. 28.

Woo, P.Y., (2005), China's electric power market: the rise and fall of IPPs, Program on Energy and Sustainable Development, Stanford University.

Woodhouse, E., (2006), The Obsolescing Bargain Redux: Foreign Investment in the Electric Power Sector in Developing Countries, Journal of International Law and Politics, Volume 1, pp. 121-246. 